\title{
Lacanian Reading of Marsha Norman's Night, Mother
}

\author{
Khadijeh Taherifard \\ Islamic Azad University Tehran Central Branch, Iran \\ E-mail: taherifardk@gmail.com \\ Razieh Eslamieh (Corresponding author) \\ Assistant Professor, Islamic Azad University Parand Branch, Iran \\ E-mail: eslami_paranduniv@yahoo.com
}

Received: 17-12-2016

Published: 01-07-2017
Accepted: 28-02-2017

doi:10.7575/aiac.ijalel.v.6n.4p.184
Advance Access Published: April 2017

URL: http://dx.doi.org/10.7575/aiac.ijalel.v.6n.4p.184

\begin{abstract}
This paper offers a Lacanian/feminist reading of Night, Mother by the American playwright Marsha Norman. The play Night, Mother will be read according to Lacan's point of view and the concepts of identity and identity formation are studied in this paper. The play will be analyzed based on the Lacanian concepts of the contrast between the Imaginary Order and the Symbolic Order, and the notion of Death Drive, suggesting that in the play Jessie represents the Symbolic Order and her mother, Thelma, represents the Imaginary Order. The notion of Death Drive and its omnipresence in Jessie's psyche is discussed and emphasized. Thelma functions as the Other for Jessie, while her father functions as the Mother, a reversal of gender roles in the Lacanian reading. Moreover, the relationship between some of the concepts are explained. It will be explicated how the play can be brought in line with a feminist reading of Lacan by reversing the stereotypical gender roles and subsequently getting close to post-feminist authors.
\end{abstract}

Keywords: The Imaginary Order, The mirror stage, The Symbolic Order, The Real, The other, The Other, Death Drive

\section{Introduction}

Marsha Norman (21 September, 1947) is an American novelist, playwright, and screenwriter. She was awarded the Pulitzer Prize for Drama for the play Night, Mother (1983). She wrote lyrics for Broadway musicals as The Secret Garden (1991), for that she got a Tony Award and she has also won the Drama Desk Award for Outstanding Book of a Musical, The Red Shoes (1993) and also the libretto for The Color Purple (2005). Besides, her another work was the book for the musical The Bridges of Madison County. She works as a co-chair of the playwriting department in The Juilliard School.

Jacques Marie Émile Lacan (13 April 1901 - 9 September 1981) is the French psychiatrist and psychoanalyst that has been called "the most controversial psycho-analyst since Freud" (Bressler 58). Holding annual seminars in Paris from 1953 to 1981, Lacan affected many superior French intellectuals in the 1960s and the 1970s, particularly those related with post structuralism. His ideas were really influential in literary theory, critical theory, linguistics, sociology, 20thcentury French philosophy, film theory, feminist theory, and clinical psychoanalysis.

In this paper, the play Night, Mother by Marsha Norman will be read Mainly through Lacanian psychoanalytic theories of diverse orders as well as Other/ other.

The main focus of the paper will be on analyzing identity and identity formation. Different Orders and some other notions are discussed in the paper. Some Lacanian concepts will be considered that is the contrast between the Imaginary Order and the Symbolic Order, and the notion of Death Drive. Basically the paper suggests that in the play, Jessie represents the Symbolic and her mother, Thelma, represents the Imaginary. The notion of Death Drive and its omnipresence in the psyche of Jessie is discussed and emphasized in this paper. The paper proves that Thelma functions as the Other for Jessie, while her father functions as the Mother that is a reversal of gender roles in the Lacanian reading.

\section{Lacanian Psychoanalylitic Theories}

\subsection{Lacan's Significance and Influence in Literary Criticism}

Jacques Marie Émile Lacan (1901 - 1981) who has been considered the pioneer figure in reviving and rereading the ideas of Freud and creating a link between psychiatry and postmodernism. Lacan is considered a major and a controversial figure in psychoanalysis at the same time.

Lacan is credited to have caused the academia "return to Freud", which renewed attention to the concepts first theorized by Freud, but he also radically revised them, connected them to postmodernism, and offered a new reading of child's 
early development. It needs to be mentioned that Freud too was deeply interested in identity formation. This return to Freud was not a slavish rereading or a simple following, but a thorough reexamination of Freud's philosophy.

It can be even argued that Lacan surpasses Freud in being Freudian. He focused the attention on language instead of dreams, arguing that "the unconscious is structured like a language" (Lacan Ecrits 268). This renewed reading of Freud provides a radical reading of the concept of identity, on which this paper is based. Lacan's ideas developed a lot in his life. "The seminar of Jacques Lacan can be divided into three periods, each lasting for approximately a decade" (Voruz viii).

\subsection{The Imaginary Order, the Mirror Stage, Symbolic Order and the Real}

\subsubsection{Order in Lacanian Psychoanalysis}

According to Lacan, a child undergoes three orders or periods to form his or her identity. These orders are not necessarily chronological, but all three are present in one's psyche. These periods are concerned with his three Orders or "registers"

The first phase of Lacan's teaching is concerned with the mirror stage, narcissism, identification - and so the formation of the ego. In this phase, Lacan engages in a passionate debate with IPA analysts, seminal psychiatrists, and contemporary philosophers. ... [The] period we refer to as the later Lacan starts with Seminar XX. Following on from Lacan's recognition of the irreducibility of the real, the later teaching is characterized by a concern with the real as immovable; insistent, but also intimately bound up with language in its entirety. In this phase, jouissance characterizes human existence. (Voruz viii-ix)

The Imaginary Order, as theorized by Lacan, is the realm of imagination, images, and deception. The main ideas of this order are blending of the individual and the world, autonomy, duality, and similarity. Lacan said that this was shaped in the Mirror Stage. (Evans 33) The Mirror Stage describes the formation of the Ego (which can also be dubbed identity for our purposes) through the process of objectification which is the result of a conflict between the child's apparent imagery emergence and his or her emotional understanding. Lacan called this identification "alienation". (Evans 34-35)

When the child is six months old he or she still lacks visual coordination. The child can recognize herself or himself in a mirror. The child sees the image as a whole and the combination of this image makes a sense of contrast without the coordination of the body which is understood. At the beginning, the child feels this dissimilarity as a competition with her or his own image, because the wholeness of the image is as a threat for the child who thinks he or she is broken into pieces. The mirror stage increase an aggressive tension between the image and the subject. To settle this tension, the child identifies himself or herself with the image: this initial identification with the similar forms the Ego (the identity). Lacan believes this time of identification is a moment of triumph and pleasure, because it leads to a form of dominance that is illusory; when the child compares her or his own sense of dominance that is not stable with the mother's ability to do everything, a paradoxical aspect which is depressing might come with the joy.

The Symbolic Order is not an equivalence of language, however, as language is a part of the Imaginary and the Real as well.

Signifier is the dimension accurate to language in the Symbolic Order. The Symbolic is also the aspect of the Other; the unconscious is the discourse of this Other. This recognizable proof is the process of identity formations of the baby with something other than himself or herself. The Symbolic Order is the realm of culture as opposing to the Imaginary order of nature. The concepts of death and "lack" are significant elements in the Symbolic Order. The analyst can determine the patient's identity through working in the Symbolic order.

The Symbolic Order begins with a deception. But Imaginary is not the only Order with alienation. As a result of the shift in focus from Imaginary alienation in the small other to linguistic alienation in the big Other, Lacan is able to propose the thesis that the subject undergoes a "twofold alienation." That is to say:

There is the other as imaginary. It's here in the imaginary relation with the other that traditional Selbst-Bewusstseinor self-consciousness is instituted. . . . There is also the Other who speaks from my place, apparently, this Other who is within me. This is an Other of a totally different nature from the other, my counterpart. Society unfailingly has a certain impact on us. We gain everything from the general public. There is a ceaseless (unless the newborn child is a psychotic) connection between the imaginary and the Symbolic. (Lacan Seminars II 452)

This is how Lacan compares the Imaginary Order and the Symbolic Order:

While the image equally plays a capital role in our own domain, this role is completely taken up and caught up within, remolded and reanimated by, the symbolic order. The image is always more or less integrated into this order, which, I remind you, is defined in man by its property of organized structure. (Lacan Seminars III 9) 
The premise of the Real is the pre-linguistic unity and the desire of the newborn child for that unity that is lost through language. Also this unity is the primary element of the desire: we generally long to regain this lost wholeness. The Real could be seen through the gaps or breaks in our linguistic access to the truth. Language cannot encompass or speak to the Real. It indicates the farthest point, the incomprehensibility which is past the scope of language. It is the past which is unspeakable. The Real is entirely related with the Mirror Stage: as by the Mirror Stage, the newborn child goes into Language and loses his or her unity with the mother. This pre-linguistic unity is the formation of the ego in the Imaginary.

In this article, the Imaginary Order and the Symbolic Order and the notion of Death Drive is discussed. Thelma is in the Imaginary Order while Jessie is in the Symbolic Order. Death Drive is another notion that is discussed in this paper. Thelma has the role of Other for her daughter, Jessie, and Jessie's father has mother's role that is a change in gender role.

\subsection{Lacan's Theories of Other/other}

\subsubsection{Narcissism}

Narcissism is an integral part of the Mirror Stage and Lacan's conception of identity overall. Lacan develops Freud's concept by linking it more explicitly with its namesake, the myth of Narcissus. In Greek mythology, Narcissus, a hunter from Thespiae in Boeotia, was famous for his beauty. He was the son of Cephissus, a river god, and Liriope that was a nymph. He was really proud, in that he contempted those who loved him. Nemesis noticed his pride and attracted him to a pool, where he noticed his own reflection in the water and fell in love with it, not understanding it was just an image. He continued until he drowned.

Lacan thus defines narcissism as the erotic attraction to the image of the baby in the mirror. This erotic relation causes the primary identification that results in forming of the ego in the Mirror Stage. Both a Life Drive (Desire) aspect and an aggressive Death Drive aspect exist in Narcissism. It is related to desire, as the myth of Narcissus shows, because the baby is strongly attracted to his or her own image.

\subsubsection{Desire}

Many critics refer to the concept of desire in Lacan with the term "jouissance". In this thesis both terms are used. There is no single definition of desire or "jouissance" found in his works, and many people who have studied him for example Dylan Evans (1966-) and Bruce Fink (1941-) have argued that he has revised his definition without explicitly mentioning this fact. But it can be convincingly argued that desire belongs to the Real and the Symbolic at the same time and functions as a bridge between the Real and the Symbolic. Lacan himself says that "with jouissance we meet the only ontical to which we may confess" (Lacan Seminars V 254).

This desire is for the lost unity of the Real, lost in the Mirror Stage and the Imaginary and lust after in the Symbolic. It is related to the Oedipus Complex and the gap. It bridges the Symbolic and the Real because it is a condition of the Symbolic which wants to gain the condition of the Real.

For understanding the procedure of desire and jouissance, what we need to understand is the fact that jouissance is caused by a gap which is created by the introduction of language. We need to draw attention to the fact that when it comes to desire Lacan was heavily influenced by Kojeve and Hegel, although he mixed their views with those of Freud and then himself expanded upon them:

Hence the famous formula Lacan absorbs from Kojeve: "Man's desire is the desire of the other." This is all well and good, but Kojeve's conceptual framework does nothing to clarify Lacan's distinction between "desire" and "demand" (as is evident from the fact that the secondary literature speaks indifferently of a "demand for recognition" and a "desire for recognition" as though there were no difference between the two). The appeal to Kojeve's framework thus obliterates the distinction between demand and desire in the very gesture that offers to explain Lacan's work. (Rebate 130)

Desire necessarily has an object but because this object is positioned as imaginary in the function of drives, there will be a trail of objects that subject achieves but never the object-cause of desire. The object-cause of desire as defined by Lacan is the gaze. The relationship between the gaze and desire is formed in a way that obtaining the objects that promise to fulfill the desire will eventually posit the subject as unsatisfied (Lacan Real Gaze 23). To put it in other words, the achievement of object petit makes it an ordinary object. In such a moment the gaze ceases to be the gaze (Lacan Real Gaze 23). The chain of desire starts when the child finally understands he is not the sole object of the Other's desire and her desire lies elsewhere, as a result of which s/he tries to become that object for the Other.

\subsubsection{The Relationship between Desire and Narcissism}

If the desire is the link between the Symbolic and the Real, Death Drive is the link between the Imaginary and the Symbolic. Death Drive also strives for the lost unity of the pre-Oedipus Complex era, but instead of desire, which sublimates this need with other needs, it is narcissistic, suicidal, and nostalgic. However, we should not make the mistake to think the Desire and the Death Drive belong to completely different categories. Like everything in Lacan's philosophy, they overlap. 
Finally, each drive in a human being has Life and Death aspects. "The distinction between the life drive and the death drive is - true in as much as it manifests two aspects of the drive... every drive is virtually a death drive" (Ecrits 258 ). That is because according to Lacan every drive continues its own death, and each drive try to go beyond the pleasure principle, to the realm of "excess jouissance where enjoyment is experienced as suffering" (ibid 811).

\section{Other/ other in Marsha Norman's Night, Mother}

\subsection{Narcissism and Desire in Thelma and Jessie}

Narcissism is another integral part of the Mirror Stage and Lacan's concept of identity overall. Freud defines two kinds of narcissism: primary and secondary narcissism. Primary narcissism is "a first state, prior to the constitution of the ego and therefore auto-erotic, through which the infant sees his own person as the object of exclusive love" (Rebate, 29) and secondary narcissism is the result of the "transfer to the ego of investments in objects in the external world. Both primary and secondary narcissism seem to be a defense against aggressive drives" (Rebate, 29). Narcissism has both a Life Drive (Desire) aspect and an aggressive Death Drive aspect. Narcissism is related to desire, as the myth of Narcissus shows, because the baby is strongly attracted to his or her own image.

This shows that both Thelma and Jessie are narcissistic. That is because both the Imaginary and the Symbolic are narcissistic, however each of them represents a different aspect of it: Thelma represents the life drive of narcissism and Jessie represents the Death Drive of narcissism.

This is one of the most important dialogues in the play, in which both characters, but especially Thelma, reveal their narcissism. Thelma cannot believe that Jessie's suicide has nothing to do with her. And she wants Jessie not to commit suicide not for Jessie's well-being, but for her own, from mundane reasons like doing chores to more serious reasons like maintaining the illusory world she lives in. Similarly, Jessie has selfish and narcissistic reasons for committing suicide, from the fact that she is unsatisfied with her life to the fact that she dislikes her mother and feels that "she is not enough" (Night 13). She basically sums up her reason to suicide: "I'm just not having a very good time and I don't have any reason to think it'll get anything but worse. I'm tired. I'm hurt. I'm sad. I feel used"' (, Night 13). This is obviously a self-centered reason for ending one's life, with a disregard to how it affects the lives of the others.

While both characters are defined by their narcissism, Thelma's narcissism is more a narcissism defined by desire, while Jessie's narcissism is defined by the Death Drive. In that case they each represent the duality of narcissism first mentioned by Freud and later by Lacan. Lacan considers desire to be a feature of the Imaginary and Death Drive a feature of the Symbolic. And reading the play we will see very clearly that the most defining characteristic of Jessie is a characteristic of the Symbolic Order that is the Death Drive. As a suicidal depressed patient, it is no surprise that it is so.

This desire is for the lost unity of the Real, lost in the Mirror Stage and the Imaginary and it is wanted in the Symbolic. It is related to the Oedipus Complex and the gap. It bridges the Symbolic and the Real because it is a condition of the Symbolic which wants to gain the condition of the Real. According to Jacques Lacan, object petit a ("object little-a") stands for object of desire that is impossible to achieve. It can be called the object cause of desire. Lacan insisted that the term should not be translated, "thus acquiring the status of an algebraic sign" (Lacan, Ecrits114). Object petit a is defined as the remained part left behind by the introduction of the Symbolic that exists in the Real.

This process can be easily seen in Thelma. This might seem contradictory as desire is considered by Lacan to be a feature of the Symbolic rather than the Imaginary, and this thesis argues that Thelma represents the Imaginary. But it is not so. As it was mentioned in the beginning of the chapter the psyche of every individual is complex and the characters cannot be argued to be solely Imaginary or solely Symbolic. It should also be noted that according to Lacan these three stages - the Imaginary, the Symbolic, and the Real - are not chronological levels that end and follow each other, but they are states that overlap in the entire life of people. The initial two Stages, the Symbolic and the Imaginary empower Lacan to epitomize a partitioned subject in which the semantic, the individual and the social measurements are interconnected.

Having said that, Thelma's desires are not a feature of Imaginary but for Imaginary and this exhibits how her character is centered on the Imaginary. Thelma is a character who wants to satisfy her immediate desires. She wants to enjoy food, while Jessie hates foods like okra and milk. She wants to rest, and more importantly, she strives to live. She beseeches Jessie to live, and Jessie knows that contrary to her protestation Thelma will not cease to live when she dies. She arranges everything in a way to make sure that Thelma's desires are catered to. And right after her death Thelma quickly goes to the phone and contacts her son, and follows Jessie's instructions. If Jessie represents the will for death Thelma represents the will for life.

\subsection{Thelma as the Other}

In this section it will be argued that Thelma functions as the Other for Jessie, while her father functions as the Mother, the lost unity of the Imaginary, a reversal of gender roles in the Lacanian reading. In the previous section we argued that Jessie's psyche is trapped in the Symbolic phase. The Symbolic is the dimension of the Other; the unconscious is the discourse of this Other (Evans 42). If Jessie is in Symbolic she has to have a relationship with her Other. There are two others involved, "The little other is the other who is not really other, but a reflection and projection of the Ego. He [autre] is simultaneously the counterpart and the specular image. The little other is thus entirely inscribed in the imaginary order" (Evans 133).

Regulating desire in the Oedipus complex is done by the realm of the Law. The analyst is able to determine patient's identity in these cases by working in the Symbolic order. This is observed in Jessie. Looking at this definition we see 
clearly how Thelma functions as the Other for Jessie. Jessie feels connected and the same with her father. She feels he was happy and that he understood her and she preferred living with her. And then her mother Thelma comes along and cuts them apart.

\section{Conclusion}

\subsection{Other/ other in Marsha Norman's Night, Mother}

This paper is an attempt to analyze a play by Marsha Norman - Night, Mother and - through the projects of character identity and personality development based on Lacan's theories, contrasted with a feminist response and women's activist perusing of such contentions, that is current penchants of post-feminist or poststructuralist feminism. The second chapter of the thesis is a summary of Lacanian and post-feminist theories.

Marsha Norman's play Night, Mother is perused through a Lacanian and feminist thoughts.

The article centers on two Lacanian theories: the distinguishing between the Imaginary Order and the Symbolic Order, and the idea of Death Drive. Essentially the paper recommends that in the play the character of Jessie speaks to the Symbolic Order and her mother, Thelma, speaks to the Imaginary Order. The characters were analyzed to show how their psyches mirror these Lacanian Orders.

The idea of Death Drive and its inescapability in the mind of Jessie was talked about and stressed upon in this area. The article demonstrated that Thelma represents the Other for Jessie, while her father is basically the Mother, an inversion of sexual orientation parts in Lacanian analysis.

At last an analysis of feminist responses to the play and feminist readings of Lacanian theories was advanced. This play casts Thelma in the role of Other for the psyche of Jessie, and casts Jessie's father as her Lacanian Mother. This reversal of gender roles shows that Norman's witting or unwitting Lacanian psychoanalysis is closer to feminists like Kristeva and Irigaray in which phallus is symbolic.

\subsection{Findings}

This study shows that Lacanian conception of identity is very useful in understanding feminist plays written by feminist playwrights. Night, Mother is a play written with a mindset to represent feminist mentality, and is considered prominent in the history of $20^{\text {th }}$ century drama. Our understanding of the play is enriched by a Lacanian concept of identity. Lacan's psychoanalysis is useful in understanding the narrative of female characters and female voices.

The controversy regarding the feminist aspects of Lacan's philosophy is still going on, as mentioned in theories. While many feminists find the ideas of Lacan sexist and phallocentric, it was mentioned in this paper that many other feminist thinkers such as Kristeva, Irigaray, and Cixous are influenced by Lacan, and they have presented their post-feminist ideas through an understanding of his psychoanalysis.

There are a few researches on Marsh Norman's works like Feminist Concerns in Marsha Norman's plays: a Critical Study, a PhD thesis by Hetal J. Mehta defended at Saurashtra University. The other similar research project to this thesis is an MA thesis entitled A Psychoanalytic Feminist Study of Marsha Norman's Getting Out and Night, Mother which was defended in China and consulted by Nancy Chodorow. There are also a limited number of research projects which have applied Lacanian theory to the plays of Marsha Norman. One is a paper by Alieyh Alsadat Jafari and Shahram Kiaei titled "Lacanian Psychoanalytical Theories in Marsha Norman's Night, Mother", which mainly deals with Lacan's theories of master/slave.

This thesis does not claim to resolve this controversy, however it provides a reading of feminist plays which match perfectly with Lacanian theories, and this implies that Lacan's theories are not incompatible with feminism. Ultimately, there are very few sources and research projects similar in subject-matter to this thesis, and the major ones are the ones already mentioned. However, this paper is new and can elaborate on this work by adding some more hints and prepare the field for more attention to Norman's works.

This thesis also finds that Marsha Norman's plays can be read through feminist and Lacanian tenets. This reading provides us with the understanding that Marsha Norman's characters are properly constructed and the psychology of her characters correctly correspond-to with psychoanalysis theories - Lacanian ones in this thesis - and also, by providing a voice to her characters who are female, Marsha Norman's plays are both feminist in the traditional sense and in the post-feminist sense.

\section{References}

Carveth, Donald L. "Some Reflections on Lacanian Theory in Relation to Other Currents in Contemporary Psychoanalysis". Unpublished Paper presented to the Toronto Psychoanalytic Society, March, 1987. York University website.

Chiesa, Lorenzo. Subjectivity and Otherness: A Philosophical Reading of Lacan. Short Circuits series. Ed. by SlovajZizek. 2007. London: MIT Press.

Cixous, Hélène. Coming to Writing and Other Essays. Trans.-Deborah Jenson. New York: Rutgers. 1991.

Cuddon, J. A. A Dictionary of Literary Terms. Harmondsworth: Penguin Books.1984

Dowling, David. Mrs. Dalloway: Mapping Streams of Consciousness. 1992. Twayne Publishers. 
Evans, Dylan. An Introductory Dictionary of Lacanian Psychoanalysis. 2006. London and New York: Routledge.

Fink, Bruce. Lacan to the Letter: Reading Lacan Closely. 2002. Minnesota: University of Minnesota Press.

Gamble, Sarah. The Routledge Companion to Feminism and Postfeminism. 2001. London: Routledge.

Homer, Sean. Jacques Lacan: Routledge Critical Thinkers. 2005. London and New York: Routledge.

Irigaray, Luce. Ethics of Sexual Difference. Trans. Carolyn Burke, Gillian C. Gill 1980. New York: SUNY Press.

Jacobus, Mary. The Poetics of Psychoanalysis: In the Wake of Klein. 2005. Oxford: Oxford University Press.

Kristeva, Julia. Desire in Language: A Semiotic Approach to Literature and Art. Fifth Ed. Trans. by Thomas Gora. 1983. New York: Rutledge.

Lacan, Jacques. Écrits: A Selection. Trans. Bruce Fink. 2002. New York and London: W. W. Norton.

---. The Four Fundamental Concepts of Psychoanalysis. Trans. Alan Sheridan. Edited by Jacques-Alain Miller. 1978. Paris: Éditions du Seuil.

---. The Seminars of Jacques Lacan: Book I. Trans. J. Forrester. Edited by Jacques-Alain Miller. 1988. Cambridge: Cambridge University Press.

---. The Seminars of Jacques Lacan: Book II. Trans. by S. Tomaselli. Edited by Jacques-Alain Miller. 1988. Cambridge: Cambridge University Press.

---. The Seminars of Jacques Lacan: Book III. Trans. R. Grigg. Edited by Jacques-Alain Miller. 1993. New York: WW Norton Press.

---. The Seminars of Jacques Lacan: Book V. Edited by Jacques-Alain Miller. 1998. New York: WW Norton Press.

---. The Seminars of Jacques Lacan: Book VII. Trans. By D. Porter. Edited by Jacques-Alain Miller. 1992. New York: WW Norton Press.

McAfee, Noëlle. Routledge Critical Thinkers: Julia Kristeva. 2004. New York: Routledge.

McGowan, Todd. The Real Gaze: Film Theory after Lacan. New York: SUNY Press.

Mehta, Hetal J. Feminist Concerns in the Plays of Marsha Norman: A Critical Study. PhD Thesis. Saurashtra University. 2010. Saurashtra University Website.

Mohler, Courtney Elkin. "Nostalgia, Irony, and the Re- Emergence of the Reified American Indian Other in August: Osage County". Text \& Presentation, 2010: The Comparative Drama Conference Series, 7. ed. Kiki Gounaridou. Jefferson, NC: McFarland, 2010: 130-142.

Norman, Marsha. Getting Out. 1979. New York: Dramatic Services Inc.

---. Night, Mother. 1983. New York: Dramatic Services Inc.

Rabaté, Jean-Michel (Ed). Cambridge Companion to Lacan. 2003. Cambridge: Cambridge University Press.

Salecl, Renata and SlovaiZizek (Eds). Gaze and Voice as Love Objects. 1996. Durham: Duke University Press.

Spencer, Jenny S. Feminist Theories for Dramatic Criticism. 1993. London: Gateway.

Stavrakakis, Yannis. Lacan\& the Political. 1999. London and New York: Routledge.

Voruz, Veronique and Bogdan Wolf (Ed). The Later Lacan. 2012. New York: SUNY Press.

Wolf, Teresa L. "Through the Feminist Lens: Application of Feminist Critical Dramatic Theory to Selected Works of Modern Drama”. Washington State University Website. 2001.

Zakin, Emily. "Psychoanalytic Feminism", The Stanford Encyclopedia of Philosophy (Summer 2011 Edition), Edward N. Zalta (ed.) 